UCRL-ID-139146

\title{
Plutonium Immobilization Project Project Office Quality Assurance Program Description Revision 1
}

\author{
R. Holler
}

Westinghouse Savannah River Company

April 30, 1998

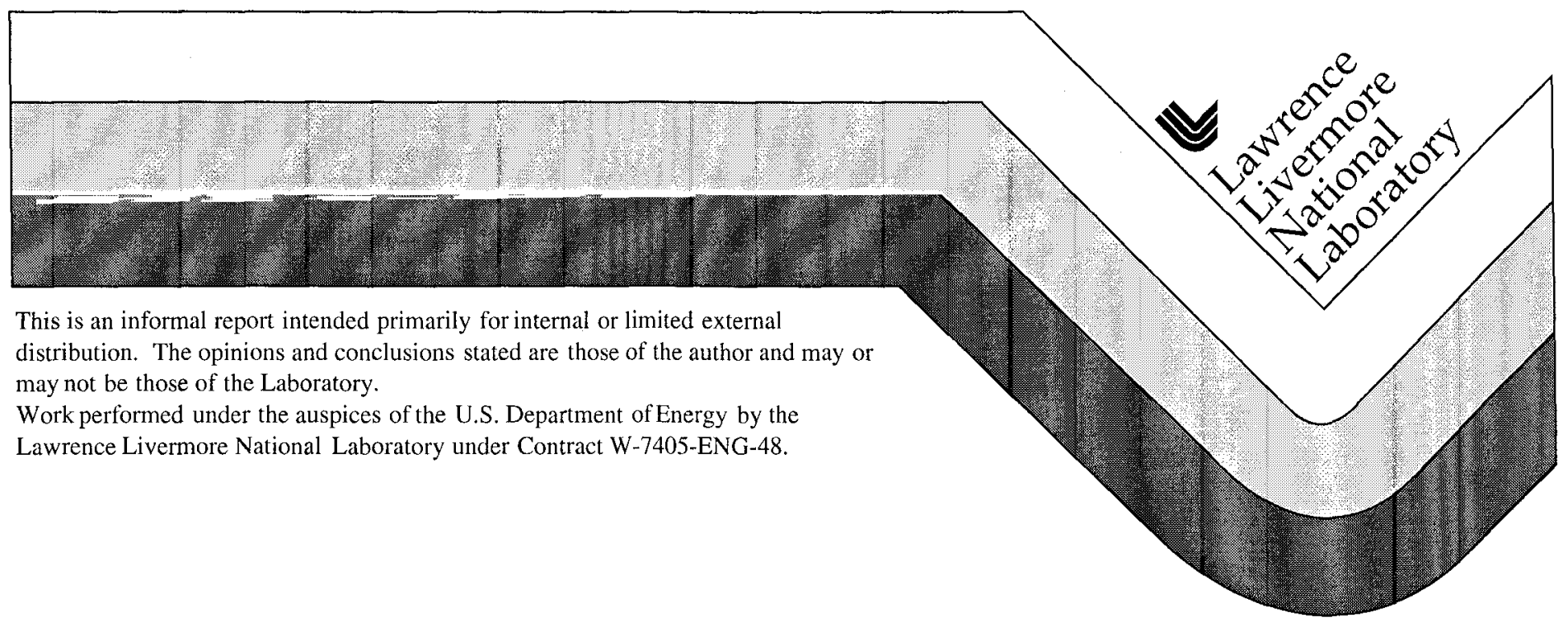




\section{DISCLAIMER}

This document was prepared as an account of work sponsored by an agency of the United States Government. Neither the United States Government nor the University of California nor any of their employees, makes any warranty, express or implied, or assumes any legal liability or responsibility for the accuracy, completeness, or usefulness of any information, apparatus, product, or process disclosed, or represents that its use would not infringe privately owned rights. Reference herein to any specific commercial product, process, or service by trade name, trademark, manufacturer, or otherwise, does not necessarily constitute or imply its endorsement, recommendation, or favoring by the United States Government or the University of California. The views and opinions of authors expressed herein do not necessarily state or reflect those of the United States Government or the University of California, and shall not be used for advertising or product endorsement purposes.

Work performed under the auspices of the U. S. Department of Energy by the University of California Lawrence Livermore National Laboratory under Contract W-7405-Eng-48.

This report has been reproduced directly from the best available copy.

Available to DOE and DOE contractors from the Office of Scientific and Technical Information

P.O. Box 62, Oak Ridge, TN 37831

Prices available from (423) 576-8401

http://apollo.osti.gov/bridge/

Available to the public from the National Technical Information Service

U.S. Department of Commerce

5285 Port Royal Rd., Springfield, VA 22161

http://www.ntis.gov/

OR

Lawrence Livermore National Laboratory

Technical Information Department's Digital Library

http://www.llnl.gov/tid/Library.html 


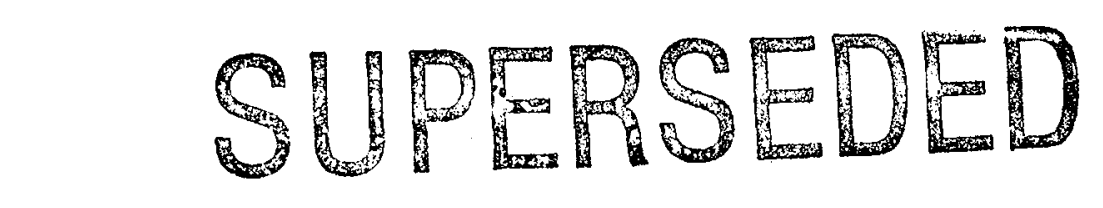

\section{PLUTONIUM IMMOBILIZATION PROJECT}

PROJECT OFFICE

\section{QUALITY ASSURANCE}

\section{PROGRAM DESCRIPTION}

February 9, 1999

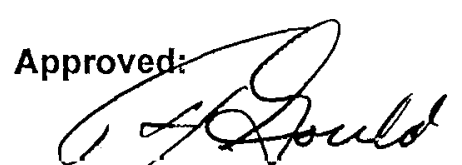

Thomas H. Gould, Jr., PIP Program Leader

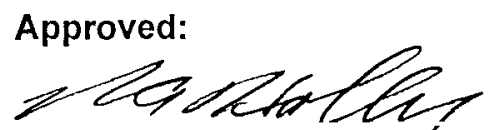

Robert A. Holler, PIP QA Program Manager
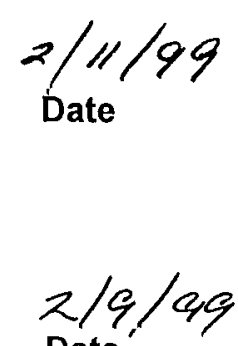

Date 
TABLE OF CONTENTS

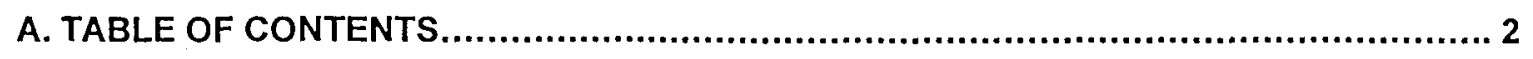

B. MANAGEMENT'S QUALITY ASSURANCE POLICY STATEMENT $\ldots \ldots \ldots \ldots \ldots \ldots \ldots \ldots \ldots . \ldots . \ldots \ldots$

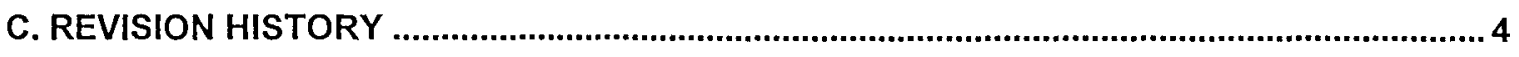

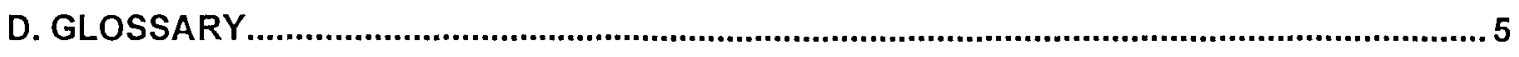

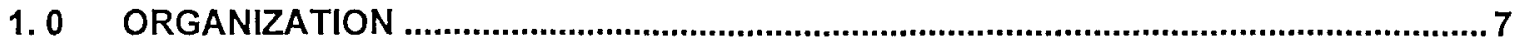

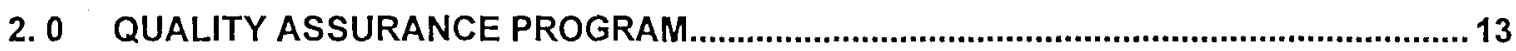

3. 0 DESIGN CONTROL.................................................................................TITE SPECIFIC

4. 0 PROCUREMENT DOCUMENT CONTROL ...................................................... SITE SPECIFIC

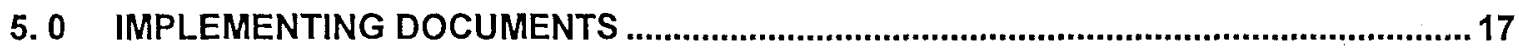

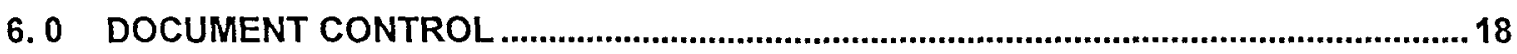

7.0 CONTROL OF PURCHASED ITEMS AND SERVICES .................................SITE SPECIFIC

8. 0 IDENTIFICATION AND CONTROL OF ITEMS..............................................SITE SPECIFIC

9.0 CONTROL OF SPECIAL PROCESSES .................................................... SITE SPECIFIC

10.0 INSPECTION ......................................................................................TITE SPECIFIC

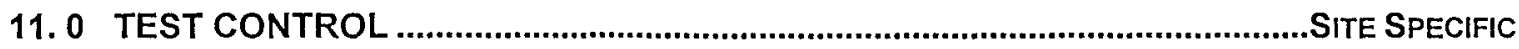

12. 0 CONTROL OF MEASURING AND TEST EQUIPMENT ................................SITE SPECIFIC

13. 0 HANDLING, STORAGE AND SHIPPING ...................................................SITE SPECIFIC

14. 0 INSPECTION, TEST AND OPERATING STATUS ..............................................TIE SPECIFIC

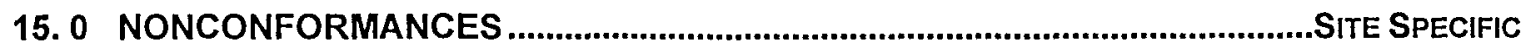

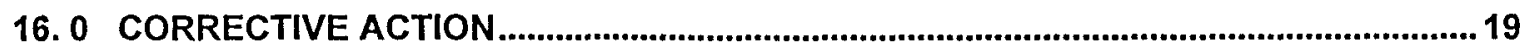

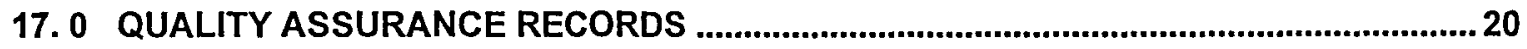

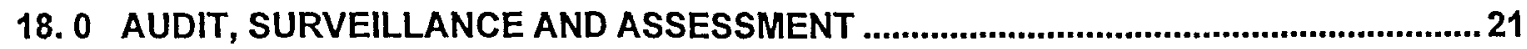
SUPPLEMENT I SOFTWARE ............................................................................... Site Specific

SUPPLEMENT II SAMPLE CONTROL ..................................................................... Site Specific SUPPLEMENT III SCIENTIFIC INVESTIGATION ........................................................ Site Specific SUPPLEMENT IV FIELD SURVEYING ........................................................................ Site Specific SUPPLEMENT $V \quad$ CONTROL OF THE ELECTRONIC MANAGEMENT OF DATA........... Site Specific APPENDIX A HIGH-LEVEL WASTE FORM PRODUCTION.................................... Site Specific APPENDIX B STORAGE AND TRANSPORTATION ............................................... Site Specific APPENDIX C MINED GEOLOGIC DISPOSAL SYSTEM........................................... Site Specific 


\section{PLUTONIUM IMMOBILIZATION PROJECT QA PROGRAM DESCRIPTION}

\section{B. MANAGEMENT'S QUALITY ASSURANCE POLICY STATEMENT}

"The quality assurance activity involves the establishment and implementation of the Quality Assurance Program and the development of a Quality Assurance Plan and Procedures. Quality Assurance provides the plans, procedures and controls that are required for repository acceptance and the immobilization plant licensing and design activities."

[Source: The Integrated Research Development and Testing Plan for Immobilization, FMDP98-064, July 1998]

The Plutonium Immobilization Project (PIP) has a policy that all development, testing and operational activities be planned and performed in accordance with its customer's needs and expectations, and with a commitment to excellence and continuous improvement.

The Immobilization Development and Testing (D\&T) Quality Assurance Program establishes implementation requirements which, when completed, will ensure that the program development and test activities conform to the appropriate QA requirements. In order for the program to be effective, a designated quality lead must be in place at the Project Office and each participating site.

This Quality Assurance Program Description applies to the immobilization Project Office activities. Each participating site in the immobilization project shall write and follow a tailored Quality Assurance Program. These programs are based primarily on the DOE/RW 0333P Quality Assurance Requirements and Description Document (0333P) for the Civilian Radioactive Waste Management Program, as set forth in the DOE Quality Assurance Requirements Document for the Fissile Materials Disposition Program (FMDP QARD). 10 CFR Part 60, Subpart G, Quality Assurance and 10 CFR 830.120, Quality Assurance Requirements, have also been used in the development of this document. Consequently, as these documents are revised, they will be evaluated for impact and applicability to the D\&T QAPD and the site specific QA Programs.

Compliance with the Immobilization D\&T QAPD and the site-specific QA programs and procedures will assure that our project deliverables meet the high standards of quality expected by the Department of Energy. 
PIP-98-023

Revision 1

\section{REVISION HISTORY}

$\begin{array}{cll}\text { REVISION } & \text { DESCRIPTION OF REVISION } & \text { REVISION DATE } \\ 0 & \begin{array}{l}\text { Initial issue of the Quality Assurance } \\ \text { Plan, PIP-98-023. }\end{array} & \text { April 30, 1998 } \\ & \begin{array}{l}\text { Revised to QAPD format based } \\ \text { on DOE MD comments. No revision } \\ \text { bars used. Supersedes QA Plan } \\ \text { PIP-98-023 dated April 30, 1998. }\end{array} & \text { February 9, 1999 }\end{array}$




\section{GLOSSARY}

[Definitions shown are additions or clarifications to the GLOSSARY provided in the 0333P, Rev, 8]

Activity: A directed process working toward an objective. Activities include programmatic functions; facility operations, scientific research experiments; development of prototype and test equipment and software, chemical processes; accelerator, computer and facility operations; and all forms of technical services and administrative functions.

Activity leader: The line manager responsible for an activity or group of activities covered by a QA plan. The activity leader may be at any level within the organization. Examples of activity leaders may include supervisors, division leaders, facility managers, group leaders, project leaders, project engineers, principal investigators, and lead experimenters.

Affected organizations: An organization performing Program work subject to QARD requirements whose organizational relationships are defined in the D\&T Program documents. The Plutonium Immobilization Project sites are affected organizations.

Assessment: An audit, quality surveillance, readiness review or management selfassessment performed by D\&T Program personnel and other independent quality professionals and technical specialists in order to verify and validate quality performance, evaluate the level of excellence an organization is providing and/or recommend quality improvement actions.

Document: Recorded information that describes, defines, specifies, reports, certifies, requires, or provides data or results. This information can be written, pictorial, photographic, or computer media form.

ES\&H: Environment, Safety \& Health. Generally includes activities designed to protect the environment, ensure the safety and health of employees and the public, and to meet regulatory requirements in these areas.

FMDP QARD: DOE Quality Assurance Requirements Document for the Fissile Materials Disposition Program.

Graded approach: A method that provides for application of management controls commensurate with the consequences and probability of failure risk.

Implementing procedure: A document that specifies or describes how an activity is to be performed.

Inspection: A quality assurance program verification that is used to verify whether an item conforms to specified technical criteria. An inspection is an examination or measurement to verify whether an item or process meets specified requirements.

D\&T: Immobilization Development and Testing.

Plan: A scheme or method formulated beforehand, for performing a specific activity.

Policy: A basic guiding principle provided by management.

Program: The Immobilization Development and Testing Program under the Plutonium Immobilization Project. 
QA: Quality Assurance.

QA Plan: A facility-, site-, or activity-level document that details the implementation of QA. The QA Plan may be referenced in other facility-, site- or activity-level documents.

Quality: The degree to which an item or process meets or exceeds the user's requirements and expectations.

Quality surveillance: This term is used interchangeably with 'surveillance' except when a conflict arises with the NRC use of the term 'surveillance'.

Record: A completed document or other media that provides objective evidence of an item or process.

Risk: A quantitative or qualitative expression of possible loss, which considers both the probability of an occurrence and the consequences of that event.

Testing (in an experiment or laboratory): The determination of the response of a material, item or system by subjecting it to a set of physical, chemical environmental, or other conditions.

Validation: An activity that demonstrates that an item or process will perform under conditions of actual use and satisfy requirements of the user.

Work: Activities that are subject to the Quality Assurance Requirements Document. In addition work is the process of performing a defined task or activity. Examples include research and development, operations, administration, software development and use, data collection, and analysis.

0333P: DOE/RW 0333P Quality Assurance Requirements and Description Document for the Civilian Radioactive Waste Management Program. 
PIP-98-023

Revision 1

\subsection{ORGANIZATION}

1.0 GENERAL

This section establishes $Q A$ implementation requirements for creating and maintaining an organizational structure to implement the Quality Assurance Program for the Immobilization Development and Testing effort. This section also provides a description of the D\&T internal organization, external interfaces, organizational structure, requirements and responsibilities for the scope of work.

\subsection{ORGANIZATIONAL STRUCTURE}

The D\&T Program is organized with LLNL as the lead technical organization and WSRC as the lead quality assurance organization. The PIP QA Program Manager, who is responsible for quality assurance activities at the Program level and for oversight functions at the participating Lab level, fills the lead quality assurance position. This position is distinct from the WSRC Lab QA activities.

For purposes of programmatic clarity, the Project Office $(\mathrm{PO})$ is comprised of the D\&T Program Leader, PIP QA Program Manager (synonymous with PO QA) and the LLNL Planning and Staff Support function. The remaining positions are part of the D\&T Management Organization and are discussed generally in this QAPD; however, the site-specific quality assurance programs govern their work.

Figure 1.1 shows the functional D\&T organization.

\subsection{DUTIES AND RESPONSIBILITIES}

The duties and responsibilities of the Project Management Organization are described in this QAPD. Specific duties and responsibilities of those D\&T management positions responsible for achieving and maintaining quality shall be included in quality implementing procedures.

The major participants in the D\&T Program (Program) and their primary responsibilities are listed below. A number of responsibilities are shared among the participating organizations.

Lawrence Livermore National Laboratory (LLNL) - program technical lead, form characterization and qualification, ceramic form development lead, process/equipment development with plutonium, and process systems testing and validation for both conversion and immobilization. 
Westinghouse Savannah River Company (WSRC) and WSRC's Technology Center (SRTC) - program Quality Assurance Lead, partners with LLNL in several activities including form qualification and repository interface, form development, process/equipment development activities, process/product validation testing with plutonium, and technology transfer to the plant, and full scale canister pour experiments.

Argonne National Laboratory (ANL) - properties/characterization of immobilization forms, form development and performance testing.

Pacific Northwest National Laboratory (PNNL) - properties/characterization of immobilization forms, performance testing, and possibly full-scale cold canister pour experiments.

DOE/RW and its subcontractors - repository performance assessments and oversight of waste form acceptance process.

The successful deployment of immobilized surplus plutonium on the aggressive schedule set by the July 1998 Integrated Development, and Testing Plan for the Plutonium Immobilization Project will require strong cooperation and close coordination among the D\&T team, the architect-engineer (AE), the plant operations team, and DOE (MD, EM and RW). The overall program is expected to evolve from an D\&T, to design, to construction, and finally to operations. This Quality Assurance Program Description will be updated accordingly as the D\&T Program and 0333P evolve.

The following are the general quality related responsibilities of the D\&T Program management:

Quality shall be achieved and maintained by those in the D\&T organization that have been assigned the responsibility for performing work.

Verification of the quality of the work shall be conducted by persons or organizations not directly responsible for performing the work. This verification shall be performed internal to the D\&T Program and may also be verified by organizations outside the Program.

The site $Q A$ representatives are responsible for performing their site-specific quality assurance assessments and the PIP QA Program Manager is responsible for performing, coordinating or directing Program-wide assessments.

Differences of opinion involving QA Program requirements shall be brought to the attention of the appropriate management and, if not resolved, shall be elevated progressively to the highest levels of management. 


\subsubsection{D\&T Program Leader}

The D\&T Program Leader is responsible for approving this QAPD and for maintaining an organizational structure and environment conducive to the effective implementation of the D\&T QA Program. The Program Leader has overall responsibility for the planning, resources and execution of the Immobilization D\&T Program through direction and management of the D\&T Management Team.

\subsubsection{D\&T Management Team (Activity and Task Leads)}

D\&T Management has responsibility for the successful accomplishment of the D\&T objectives. D\&T Management provides the necessary planning, organization, direction, control, resources, and support to achieve its mission objectives. Management is responsible for planning, performing, assessing, and improving the quality of work.

D\&T Management is responsible for establishing and implementing policies, plans, and procedures that control the quality of work, consistent with the provisions of the site specific QA Programs. Management is responsible for defining quality, developing appropriate plans to attain quality, providing support of the workers in pursuit of quality, and ensuring quality achievement.

D\&T Management has various QA responsibilities that include:

- ensuring that adequate technical and QA training is provided for personnel performing activities important to the satisfaction of D\&T objectives;

- ensuring compliance with all applicable regulations and requirements pertaining to D\&T activities, and appropriate state and local laws;

- ensuring that personnel adhere to procedures for the development, identification, control, and protection of QA records, which includes licensing information and data;

- exercising the authority and responsibility to stop unsatisfactory work such that cost and schedule do not override environmental, safety, health or quality considerations;

- identifying, investigating, reporting, and correcting quality problems.

\subsubsection{PIP QA Program Manager}

The PIP QA Program Manager reports to the D\&T Program Leader and has the authority and overall responsibility to independently assess the effective implementation of the D\&T QA Program. Additional authorities and responsibilities of the PIP QA Program Manager include the following:

- scheduling and conducting QA assessments; 
- maintaining liaison with Site QA Representatives and other affected organizations;

- preparing, as appropriate, and reviewing internal procedures that implement the provisions of this QAPD;

- reviewing and approving participating Lab QAPDs and Implementing matrices;

- tracking, performing trend analysis, and reporting quality problem areas; and

- providing for the processing of documentation concerning conditions adverse to quality.

The PIP QA Program Manager will have direct access to responsible management at a level where appropriate action can be affected; be sufficiently independent from cost and schedule considerations; have the organizational freedom to communicate with management, and have no other responsibilities unrelated to the quality assurance program that would prevent full attention to quality assurance matters.

D\&T management policy grants the QA organization sufficient authority, access to work areas, and organizational freedom to identify quality problems, recommend solutions, verify implementation of solutions, and assure that unsatisfactory conditions are controlled until proper disposition has occurred.

In addition to the above responsibilities and authorities, the PIP QA Program Manager will:

- develop, establish, and interpret D\&T QA policy to ensure effective implementation;

- interface with D\&T staff, and others, relating to quality assurance matters;

- assist other D\&T organizations with quality planning, documentation, quality measurement, and problem identification and resolution;

- provide guidance to all D\&T organizations concerning identification, control, and protection of QA records; and

- interface with DOE MD Quality Assurance on matters affecting the D\&T Quality Assurance Program.

- Review and acceptance of participating Lab QAPDs and Requirements Matrices. 


\subsubsection{Planning and Staff Support LLNL}

The Project Office function of Planning and Staff Support at LLNL is responsible for:

- Developing and maintaining the D\&T Project QA Records Management System;

- Developing and maintaining the D\&T Project Document Control System and;

- Developing and maintaining the D\&T Project Correspondence Control System. 
Figure 1.1

Immobilization D\&T Organization

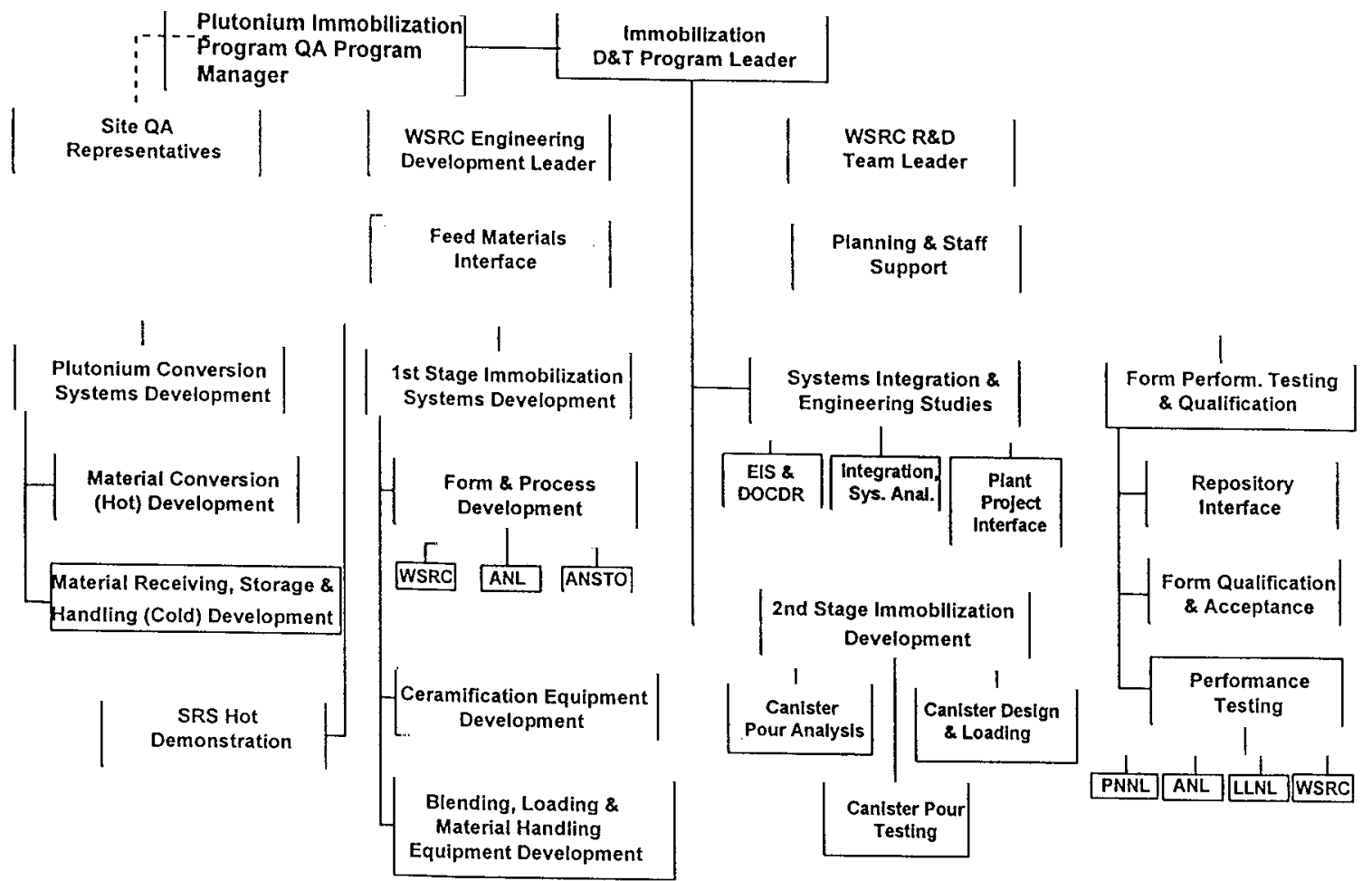




\subsection{QUALITY ASSURANCE PROGRAM}

\subsection{General}

This QAPD and those QA Programs developed by the participating Labs are based upon 830.120 and the 0333P, as endorsed by the DOE FMDP QARD.

This section establishes QA implementation requirements for planning and maintaining the QA Program. It also establishes requirements for topics related to the QA Program such as planning, indoctrination and training, qualification of assessment personnel, quality improvement and trending. The reason for this is to assure that QA activities are performed under controlled conditions, including the use of appropriate equipment, that individuals are trained, and that prerequisites for a given activity have been satisfied.

This QAPD is applicable to the D\&T Project Office personnel performing work under the national integrated Plutonium immobilization activities and is based principally on the $Q A$ requirements given in the following documents:

- DOE/MD Quality Assurance Requirements Document (MD QARD).

- DOE/RW-0333P, Quality Assurance Requirements and Description (0333P), revision 8.

- 10 CFR Part 60, Subpart G, Quality Assurance.

- 10 CFR Part 830.120, Quality Assurance Requirements.

- NOTE: As these documents change, they will be evaluated for impact and applicability to the D\&T Program.

PIP QA Program Manager reviews revisions to 0333P and makes recommendation on incorporation of changes into D\&T Program quality assurance implementing documents, as appropriate.

\subsection{Quality Assurance Program Documents}

A. The D\&T Project Office (PO) and participant Labs (LLNL, ANL, PNNL, WSRC) have established a Quality Assurance Program Description applicable to their scope of work that integrates the requirements of DOE/RW-0333P and 10 CFR 830.120 into work processes. The participants have established a structured system of quality assurance implementing documents that: 
1. Provide for top down implementation of requirements or, if stipulated in procurement documents, work to the quality assurance implementing documents of the next-higher-level organization.

2. Accommodates the size and location(s) of the organization, the organizational structure, and the nature of the work such that management processes are carried out efficiently and effectively.

3. Provides positive control over external interfaces between organizations and internal interfaces within an organization. An interface exists when one organization prescribes an activity or requirement to, or shares an activity or requirement with, another organization.

\subsection{Surveillances}

Surveillances are conducted to evaluate the quality of selected D\&T activities. Surveillances are:

A. Conducted to verify the quality of work in progress; to identify conditions adverse to quality; to ensure that the prompt corrective action is taken by management responsible for performing the work; and to verify the timely implementation of corrective action.

B. Performed by personnel who are knowledgeable about, and not directly responsible for, the work under surveillance.

C. Documented in a report to appropriate management.

The PO QA will conduct surveillances in accordance with WSRC Quality Assurance Manual 1Q, Procedure QAP 18-2, Quality Assurance Surveillance.

\subsection{Management Assessments}

Senior management performs or directs the performance of management. assessments by personnel outside the quality assurance organization.

A. Management assessments are planned and documented, and performed annually.

B. Management assessments evaluate the:

1. Adequacy of the organizational structure and staff.

2. Adequacy and effectiveness of the quality assurance program.

3. Adequacy of the personnel qualification and training program.

4. Effectiveness of the nonconformance and corrective action program.

5. Adequacy of the quality assurance program management information tracking, evaluation, and reporting system. 
Management Assessments of this program will conducted in accordance with WSRC Quality Assurance Manual 1Q, Procedure QAP 18-4, Management Assessments.

\subsection{Graded Approach}

The PO applies a graded approach to the application of Quality Assurance to the D\&T activities. This ensures adequate programmatic controls where required and maintains a cost-effective level of implementation.

PO QA will implement WSRC Quality Assurance Manual 1Q, Procedure QAP 2-1, Quality Assurance Program for graded approach activities.

\subsection{Document Review}

Documents are reviewed by the affected organizations to the requirements specified by the applicable section of the 0333P.

A. Review criteria are established before performing the review. These criteria consider applicability, correctness, technical adequacy, completeness, accuracy, and compliance with established requirements.

B. Pertinent background information or data is made available to the reviewers by the organization requesting the review if the information is not readily available to the reviewer.

C. The review is performed by individuals other than the originator.

D. Reviewers are technically competent in the subject area being reviewed.

E The scope of the review considers all aspects of the document.

F. Comments resulting from the review are documented and resolved before approving the document.

The PO QA will conduct document reviews in accordance with WSRC Quality Assurance Manual 1Q, Procedure QAP 5-1, Instructions, Procedures and Drawings. The PO LLNL shall review documents in accordance with LLNL D\&T Quality Implementing Procedure LQIP 6.2, Document Review.

\subsection{Quality Assurance Program Information Management}

A. The PO QA shall establish and maintain a quality assurance information system to facilitate effective communication of the status of the quality assurance program; status of resolution of issues, trends, and significant conditions adverse to quality; and summary of quality assurance overview results.

Each Site QA Representative reports quality assurance program information to internal management in accordance with existing programs and to the PIP QA Program Manager as the documents are issued. The documents consist of Audit Reports, Surveillance Reports, Nonconformance Reports, Corrective Action Reports, Status 
Reports and similar documents.

C. The PO QA will consolidate and summarize the participant information and report to project management, on a quarterly basis, information related to the status of the QA program.

2.8 Personnel Indoctrination, Training, and Qualification

The PO personnel shall be indoctrinated and trained commensurate with the position requirements. This includes indoctrination with the appropriate codes and standards, the QA requirements documents, this QAPD and applicable implementing procedures or documents.

The PO QA will conduct indoctrination and training in accordance with WSRC Quality Assurance Manual 1Q, Procedure QAP 2-2, Personnel Training and Qualification.

\subsection{Implementation Matrix}

The PO shall implement the applicable sections of WSRTC RW 0333P Requirements Implementation Matrix, WSRC-IM-9573 and the applicable sections of LLNL Development and Testing Quality Implementing Procedures QARD Requirements Matrix. 


\subsection{IMPLEMENTING DOCUMENTS}

\subsection{GENERAL}

A program is in place which ensures that work identified as being important to meeting the requirements of the 0333P is prescribed by, and performed in accordance with, written implementing documents.

The implementing documents identified for use in this QAPD shall be evaluated and augmented or clarified as required, prior to use by the PO. This evaluation shall be documented on a Use of Existing Procedure form and shall be reviewed and concurred with by the PO QA and PIP Program Lead.

The PO QA will conduct document reviews in accordance with WSRC Quality Assurance Manual 1Q, Procedure QAP 5-1, Instructions, Procedures and Drawings.

The PO LLNL shall review documents in accordance with LLNL D\&T Quality Implementing Procedure LQIP 6.2, Document Review. 


\subsection{DOCUMENT CONTROL}

\subsection{GENERAL}

This section describes the program that ensures that D\&T Program documents, including changes thereto, are reviewed for adequacy, approved for release, and distributed to and used at the location where the work is being performed.

Documents and changes to documents that specify technical requirements, quality requirements or prescribe work are reviewed for adequacy, correctness, and completeness, according to the requirements of Section 5.0, prior to approval and issuance.

The distribution and use of documents, including changes and editorial corrections to documents, is controlled.

The LLNL PO document control activities shall be performed in accordance with LLNL D\&T Quality Implementing Procedure LQIP 6.1, Document Control.

WSRC procedures shall be distributed in accordance with WSRC Quality Assurance Manual QAP 6-1, Document Control. 


\subsection{CORRECTIVE ACTION}

\subsection{CONDITIONS ADVERSE TO QUALITY}

This section describes the program for identifying and correcting conditions adverse to quality in the D\&T program.

A condition adverse to quality is identified when a 0333P or an implementing document requirement is not met. Conditions adverse to quality are classified in regard to their significance, and corrective actions are taken accordingly. Two categories of classification are established: conditions adverse to quality and significant conditions adverse to quality.

Conditions adverse to quality are documented and reported to the appropriate levels of management responsible for the conditions and to the quality assurance organization for tracking. Responsible management investigates and documents the investigation of conditions adverse to quality. The quality assurance organization concurs with the proposed remedial action to ensure that quality assurance program requirements are satisfied.

PO QA will evaluate and control conditions adverse to quality in accordance with WSRC Quality Assurance Manual 1Q, Procedure QAP 16-1, Corrective Action System.

\subsection{TRENDING}

The PO QA establishes criteria for determining adverse quality trends. Reports of surveillance results and conditions adverse to quality are evaluated to identify adverse quality trends and help identify root causes. Trend evaluation is performed in a manner and at a frequency that provides for prompt identification of adverse quality trends. Identified adverse trends are reported to the organization responsible for corrective action.

The PO QA will conduct trend analysis in accordance with WSRC SRTC Manual L1, Procedure 8.19 SRTC Quality Assurance Trending Program. 
PIP-98-023

Revision 1

\subsection{QUALITY ASSURANCE RECORDS}

\subsection{GENERAL}

The LLNL PO is the designated lead organization for D\&T Project QA Records. A program for ensuring that the quality assurance records important to the D\&T Project effort are controlled and maintained is established in the form of the Plutonium Immobilization Project Records Management Plan. 
PIP-98-023

Revision 1

\subsection{AUDITS, SURVEILLANCE AND ASSESSMENT}

\subsection{GENERAL}

A program for performing internal quality assurance audits to verify compliance with and to determine the effectiveness and adequacy of, the quality assurance program is established. Audits will be both compliance and performance based to ensure proper program implementation and that quality products are being delivered. Audits of the participating Labs are considered to be internal audits. An audit schedule is developed annually and revised as necessary to ensure that coverage is maintained current.

Since the PO QA is a WSRC organization, internal audits conducted by other WSRC organizations on PIP activities are deemed to satisfy the requirement for a PO QA audit of WSRC PIP activities.

Audits shall be performed in accordance with WSRC Quality Assurance Manual 1Q, Procedure QAP 18-6, Quality Assurance Internal Audits. Auditors shall be qualified in accordance with WSRC Quality Assurance Manual 1Q, Procedure 2-4, Auditor/Lead Auditor Certification. 